\author{
Anna HORECZY \\ https://orcid.org/0000-0002-1000-4158 \\ Instytut Historii im. Tadeusza Manteuffla Polskiej Akademii Nauk
}

\title{
Cytaty w listach Piotra Wolframa - między średniowieczem a renesansowym humanizmem
}

\begin{abstract}
Zarys treści: Artykuł poświęcony jest roli cytatów jako miernika wpływów humanistycznych na przykładzie listów Piotra Wolframa - polskiego prawnika wykształconego we Włoszech, uczestnika soboru w Konstancji i ambitnego kurialisty. Zawarte w nich zapożyczenia z Petrarki, Cycerona, Kwintyliana i Owidiusza zostały poddane analizie i dla ostatnich trzech wykazano, że nie musiały zostać zaczerpnięte bezpośrednio z dzieł autorów starożytnych, ale mogły pochodzić ze średniowiecznych antologii.

Abstract: The article is devoted to the role of quotations as a tool to measure the impact of humanism on the example of letters of Piotr Wolfram - a Polish lawyer educated in Italy, participant of the Council of Constance, and ambitious official of the curia. Wolfram's borrowings from Petrarch, Cicero, Quintilian, and Ovid have been analysed and it has been indicated for the last three that they did not have to be borrowed directly from their authors' writings but could have been taken from medieval anthologies.
\end{abstract}

Słowa kluczowe: cytat, humanizm, listy, Petrarka, Piotr Wolfram

Keywords: citation, humanism, letters, Petrarch, Piotr Wolfram

W artykule podejmuję analizę cytatów w korespondencji Piotra Wolframa (zm. 1428), syna Fabiana z Wolbromia, prawnika i dyplomaty, który zrobił spektakularną karierę jak na swoje mieszczańskie pochodzenie. Pierwsze informacje źródłowe o nim pochodzą z 1402 r., gdy objął funkcję pisarza miejskiego we Lwowie, co wskazuje na to, że musiał już wcześniej odebrać odpowiednie wykształcenie. Zdaniem Krzysztofa Ożoga prawdopodobnie uczęszczał do jednej ze szkół krakowskich i studiował sztuki wyzwolone w Pradze, nie uzyskując wszakże stopnia naukowego ${ }^{1}$. Za hipotezą tą przemawia również fakt, że w 1408 r. wpisał się na uniwersytet prawniczy w Pradze, skąd wyjechał jednak w 1409 r. po ogłoszeniu dekretu kutnohorskiego. Pracując w kancelarii miejskiej we Lwowie (do 1407), przeprowadził jej reformę, przyczynił się także do wprowadzenia nowych formuł areng do kancelarii arcybiskupa halickiego Jakuba Strepy². W 1407 r. Wolfram jako jego przedstawiciel udał się do Kurii Rzymskiej,

\footnotetext{
${ }^{1}$ K. Ożóg, Piotr Wolfram (zm. 9 X 1428), w: Profesorowie Wydziału Prawa Uniwersytetu Jagiellońskiego, t. 1: 1364-1780, red. W. Uruszczak, Kraków 2015, s. 337-339. Odrzucić należy natomiast hipotezę B. Petryszak, że Wolfram pod koniec XIV w. studiował na Uniwersytecie Krakowskim (w okresie poprzedzającym jego odnowienie); taż, Львівський період діяльності Петра Вольфрама (1402-1407 рр.), w: Lwów: miasto - społeczeństwo - kultura. Studia z dziejów Lwowa, t. 7, red. K. Karolczak, Ł.T. Sroka, Kraków 2010, s. 181.

${ }^{2}$ R. Trawka, Arengi i motywacje w dokumentach arcybiskupa halickiego Jakuba Strepy, St. Źródł., 53, 2015, s. 59 n., 65, 68; В. Petryszak, Кар'єри публічних нотаріїв у Львові XV-XVI cm, „Średniowiecze Polskie i Powszechne”, 3 (7), 2011 ,
} 
gdzie mógł się zetknąć z humanizmem włoskim, gdyż w tym czasie jednym z sekretarzy papieskich był wybitny humanista florencki Leonardo Bruni (zm. 1444) ${ }^{3}$. Włoską formację intelektualną, przede wszystkim prawniczą, Polak mógł zdobyć w czasie kolejnych wizyt we Włoszech. W 1409 r. przebywał w Bolonii jako poseł króla polskiego do wybranego przez sobór pizański papieża Aleksandra $\mathrm{V}$ (mógł wtedy studiować prawo kanoniczne na tamtejszym uniwersytecie). Studia prawnicze kontynuował w Padwie w 1411 r., a następnie w Bolonii, gdzie uzyskał licencjat dekretów (2 IX 1413)4.

$\mathrm{Na}$ formację intelektualną Piotra Wolframa mógł wpłynąć pobyt na soborze w Konstancji, dokąd pojechał w 1415 r. jako wysłannik biskupa krakowskiego Wojciecha Jastrzębca. Sporządzał tam notatki i zbierał akta soborowe, uczestniczył w pracach komisji soborowych, współdziałał w opracowywaniu stanowiska polskiego w sprawie sporu polsko-krzyżackiego, w 1416 r. razem z Augustynem z Pizy przedstawiał przed zgromadzeniem soborowym tzw. Propositio Polonorum, a w 1418 r. odczytał relację z misji chrystianizacyjnej na Żmudzi ${ }^{5}$. Wydaje się, że istotny wpływ na jego formację mogły wywrzeć kontakty z przebywającymi w Konstancji prawnikami włoskimi, ale także wygłaszane tam mowy i kazania (niektóre z nich znalazły się w należącym do niego rękopisie BJ 1596, zob. niżej). Na soborze mógł również zetknąć się z humanizmem włoskim za sprawą obecnych tam czołowych przedstawicieli tego ruchu: Leonarda Bruniego i Poggia Braccioliniego ${ }^{6}$.

Kariera kościelna Piotra Wolframa przyspieszyła po uzyskaniu licencjatu dekretów. Udało mu się zgromadzić kilka ważnych beneficjów: kanonię poznańską (1414), kantorię wiślicką (1415) - zamienioną w 1418 r. na scholasterię gnieźnieńską, kanonię krakowską (1417), a w 1426 r. po rezygnacji ze scholasterii gnieźnieńskiej został archidiakonem krakowskim. Pełnił także prestiżową oraz intratną funkcję kolektora soborowego w Polsce (1415), a później kolektora Kamery Apostolskiej (1418-1426) 7 . Po powrocie ze studiów w Bolonii został profesorem na Wydziale Prawa Uniwersytetu Krakowskiego. Uczestniczył też w misjach dyplomatycznych jako wysłannik króla polskiego, m.in. do Zygmunta Luksemburskiego (w 1414, 1419 i 1420) w związku ze sporem polsko-krzyżackim ${ }^{8}$. Wygłaszał także mowy i kazania, które zachowały się w rękopisach Biblioteki Jagiellońskiej 2459 oraz Biblioteki Uniwersytetu Wrocławskiego I Q $87^{9}$.

Listy Piotra Wolframa z Konstancji były wielokrotnie przywoływane przez badaczy zajmujących się początkami humanizmu w Polsce ze względu na najwcześniejszy znany nam przypadek powołania się polskiego autora na Petrarkę, a także z powodu cytatów z autorów klasycznych, takich jak Cyceron, Kwintylian czy Owidiusz. Wspomniane odwołania przyczyniły się do uznania Wolframa przez niektórych

s. 175-177; taż, Львівський перiod, s. 178-194; M. Starzyński, Archiwa miejskie w średniowiecznych strategiach pamięci, w: Przeszłość w kulturze średniowiecznej Polski, t. 1, red. J. Banaszkiewicz, A. Dąbrówka, P. Węcowski, Warszawa 2018, s. 469; M. Zwiercan, Piotr Wolfram z Krakowa, w: PSB, t. 26, Wrocław 1981, s. 404; M. Wilamowski, Strepa Jakub, w: PSB, t. 44, Warszawa-Kraków 2006-2007, s. 318-320.

${ }^{3}$ M. Zwiercan, Piotr Wolfram, s. 404; G. Griffiths, Leonardo Bruni and the Restoration of the University of Rome (1406), „Renaissance Quarterly”, 26, 1973, nr 1, s. 1-10.

${ }^{4}$ J. Fijałek, Polonia apud Italos scholastica saeculum XV, t. 1: Poloni apud Italos litteris studentes et laurea donati inde a Paulo Wladimiri usque ad Johannem Lasocki collecti ei illustrati, Cracoviae 1900, s. 33 n., 36-38; M. Zwiercan, Piotr Wolfram, s. 404; M.D. Kowalski, Dlaczego warto było zostać kolektorem? Kariery papieskich kolektorów generalnych w Polsce w XV wieku, Rocz. Hist., 80, 2014, s. 135; K. Ożóg, Piotr Wolfram, s. 337 n.; A. Horeczy, Prawnicze doktoraty Polaków w Bolonii w XV wieku, Rocz. Hist., 81, 2015, s. 154.

${ }^{5}$ K. Ożóg, Uczeni w monarchii Jadwigi Andegaweńskiej i Władysława Jagiełty (1384-1434), Kraków 2004, s. 207-211; tenże, Piotr Wolfram, s. 338; M. Zwiercan, Piotr Wolfram, s. 404; G. Lichończak-Nurek, Wojciech herbu Jastrzębiec, arcybiskup i mą̇ stanu (ok. 1362-1436), Kraków 1996, s. 103.

${ }^{6}$ A. Manfredi, Papi, prelati, umanisti - libri, biblioteche, studi, „Archivio Storico Lodigiano”, 136, 2017, s. $21-34$.

${ }^{7}$ M.D. Kowalski, Dlaczego warto było zostać kolektorem?, s. 135-138.

${ }^{8}$ K. Ożóg, Piotr Wolfram, s. 338 n.

${ }^{9}$ Rkps BJ 2459, pozbawiony not proweniencyjnych, datowany był przez M. Kowalczyk na 1425 r.; taż, Krakowskie mowy uniwersyteckie z pierwszej połowy XV wieku, Kraków 1970, s. 30. Rkps Biblioteki Uniwersyteckiej we Wrocławiu I Q 87 datowany jest ogólnie na XV w.; zob. Katalog rękopisów dawnej Biblioteki Uniwersyteckiej we Wrocławiu tzw. katalog Göbera, t. 14, k. 148r-149r, <https://www.bibliotekacyfrowa.pl/dlibra/publication/10530/edition/18842> [dostęp: 11.05.2020]. 
badaczy za jednego z prekursorów humanizmu w Polsce ${ }^{10}$. Cytat bowiem bardzo często wykorzystywany jest jako miernik stopnia recepcji humanizmu, i to na najbardziej podstawowym poziomie - poprzez sprawdzenie, jakie dzieło jest cytowane lub jaki autor jest przywoływany. Badacze nieraz identyfikują pierwotne źródła cytatu (np. dzieło autora starożytnego), zakładając przy tym, że osoba posługująca się cytatem też korzystała z tego właśnie źródła. Podejście takie często okazuje się niewystarczające, co postaram się wykazać na przykładzie cytatów w listach Piotra Wolframa.

Po pierwsze, konieczne jest uwzględnienie formacji intelektualnej osoby posługującej się cytatem, „warsztatu”, z jakiego mogła korzystać, w tym własnej biblioteki. Nie można przy tym ograniczać się do sprawdzenia, czy osoba posługująca się cytatem mogła mieć dzieło danego autora w swojej bibliotece lub dostęp do rękopisu z tą pozycją. Należy też pamiętać o złożonej recepcji utworów starożytnych w średniowieczu, obejmującej także fragmenty tekstów, cytaty włączane w obręb innych tekstów, umieszczane we florilegiach, zbiorach mów i kazań, listach ${ }^{11}$. Istotne będzie zatem sprawdzenie, czy dany cytat zastosowany przez Wolframa funkcjonował również samodzielnie, w oderwaniu od pierwotnego dzieła (w czym pomocny może być np. katalog łacińskich sentencji funkcjonujących w średniowieczu opracowany przez Hansa Walthera ${ }^{12}$ ), a także, w jakim występował kontekście.

Cytat należy rozważać też w kategorii kodu kulturowego, którego zrozumienie uzależnione było od wspólnej formacji kulturowej autora i odbiorcy tekstu (przede wszystkim tych samych lektur) ${ }^{13}$. Istotny jest także cel, w jakim autor posługiwał się określonym cytatem (co chciał osiągnąć poprzez jego użycie). Ponadto należy zwrócić uwagę na problem definicji samego cytatu. W epoce kultury rękopiśmiennej nie sprawdza się klasyczna definicja cytatu jako wyodrębnionego i dosłownie przytoczonego fragmentu tekstu ${ }^{14}$. Po pierwsze, obecność cytatu w tekście nieraz nie jest w żaden sposób sygnalizowana, po drugie - trudno jest mówić o dosłownym przytoczeniu, gdy tekst tego samego dzieła $\mathrm{w}$ różnych rękopisach występował w nieco innych odmianach ${ }^{15}$. Wydaje się, że potrzebne jest szersze rozumienie cytatu, uwzględnienie także cytatów niedokładnych, transformacji czy parafrazy, zwłaszcza że nieraz cytowano z pamięci.

${ }_{10}$ J. Fijałek określał listy Wolframa jako ułożone „ad morem humanistarum”; tenże, Polonia apud Italos scholastica, s. 43. M. Zwiercan na podstawie autorów klasycznych przywoływanych w listach określił erudycję Wolframa jako humanistyczną; tenże, Piotr Wolfram, s. 405. I. Malinowska-Kwiatkowska nie tylko przypisała Wolframowi znajomość włoskiej kultury humanistycznej, ale jeszcze uznała go za czytelnika poezji Petrarki; zob. taż, I manoscritti giuridici bolognesi al collegium iuridicum dell'Università Jagellonica (il lascito di Piotr Wolfram), w: Laudatio Bononiae. Atti del Convegno storico italo-polacco svoltosi a Bologna dal 26 al 31 maggio 1988 in occasione del Nono Centenario dell'Alma Mater Studiorum, red. R.K. Lewański, Bologna-Varsavia 1990, s. 161. Zob. też I. Zarębski, Okres wczesnego humanizmu, w: Dzieje Uniwersytetu Jagiellońskiego w latach 1364-1764, t. 1, red. K. Lepszy, Kraków 1964, s. 156; N. Contieri, La fortuna del Petrarca in Polonia nei secoli XIV e XV, „Annali dell'Istituto Universitario Orientale. Sezione Slava”, 4, 1961, s. 149 n.; B. Biliński, Tradizioni italiane all’Università Jagellonica di Cracovia, Wrocław 1967, s. 31; J. Domański, Scholastyka i początki humanizmu w myśli polskiej XV wieku, Warszawa 2011, s. 77 n., 86; G. Franczak, ,,Vix imitabilis”. La Griselda polacca fra letteratura e cultura popolare, Udine-Kraków 2006, s. 56; tenże, Petrarca e gli inizi dell'umanesimo polacco, w: Premio „Città di Monselice” per la traduzione letteraria e scientifica, t. 34-35, red. G. Peron, Monselice 2007, s. 153 n.; P.W. Knoll, „A Pearl of Powerful Learning”. The University of Cracow in the Fifteenth Century, Leiden 2016, s. 236 n.

${ }^{11}$ Szerzej zob. B.M. Olsen, Les florilèges d'auteurs classiques, w: Les genres littéraires dans les sources théologiques et philosophiques médiévales. Définition, critique et exploitation. Actes du Colloque international de Louvain-la-Neuve, 25-27 mai 1981 (Louvain, 1982), Louvain-la-Neuve 1982, s. 151-164.

${ }_{12}$ Lateinische Sprichwörter und Sentenzen des Mittelalters in alphabetischer Anordnung, t. 1-5, oprac. H. Walther, Carmina medii aevi posterioris Latina, t. 2, Göttingen 1963-1967 [dalej: Walther].

13 Zob. J. Axer, Stanisław August jako Oktawian August, w: Lacina jako język elit, red. J. Axer, Warszawa 2004, s. 252; A. Axerowa, Próba klasyfikacji wtrętów tacińskich w staropolskich tekstach dwujęzycznych, w: tamże, s. 158 n.; W. Pawlak, „, O pewnym sposobie naszych literatów, że przy niewielkim czytaniu moga się łatwo wielkiemi erudytami pokazać”. Kompendia jako źródło erudycji humanistycznej, w: Staropolskie kompendia wiedzy, red. I.M. Dacka-Górzyńska, J. Partyka, Warszawa 2009, s. 45.

${ }^{14}$ A. Jarmuszkiewcz, J. Tabaszewska, Wstęp, w: Opus citatum. O cytacie w kulturze, red. A. Jarmuszkiewcz, J. Tabaszewska, Kraków 2014, s. 7-10.

${ }^{15}$ Odnosi się to w szczególności do cytatów biblijnych, gdyż przed wynalezieniem druku istniało wiele wariantów Wulgaty w zależności od rękopisu; zob. L.P. Wandel, The Reformation. Towards a New History, Cambridge 2011, s. 70. 
Biblioteka Piotra Wolframa, częściowo rozpoznana, mówi wiele o jego formacji i warsztacie pisarskim ${ }^{16}$. Badacze zidentyfikowali dotąd osiem zachowanych rękopisów, które do niego należały (BCzart. 2008, BJ 344, BJ 372, BJ 395, BJ 1350, BJ 1352, BJ 1596, Biblioteka Krakowskiej Kapituły Katedralnej [dalej: BKapKr.] 94) i jeden niezachowany rękopis z Biblioteki Załuskich. Według hipotezy Jana Słowińskiego, która nie została jednak dotąd potwierdzona przez innych badaczy, do Piotra Wolframa należał również rękopis BJ 519, zawierający Partitiones oratoriae Cycerona, formularze z kopiami listów i mów włoskich autorów głównie z końca XIV i początku XV w., w tym dużą kolekcję listów padewskiego retora Gasparina Barzizzy, a także listy Leonarda Bruniego (niektóre w wersji sprzed redakcji oficjalnego Epistolarium) oraz tegoż Dialogi ad Petrum Paulum Histrum ${ }^{17}$.

Nie wiadomo, jaką część biblioteki Piotra Wolframa stanowiły zidentyfikowane dotąd rękopisy, gdyż nie dysponujemy jej inwentarzem (w legacie sporządzonym przez niego w 1426 r. na rzecz uczniów gnieźnieńskiej szkoły katedralnej nie zostały wymienione książki) ${ }^{18}$. W bibliotece tej znajdowały się głównie dzieła z zakresu prawa kanonicznego i teologii pastoralnej, a także retoryki. Księgozbiór ten był ukierunkowany na cele praktyczne, gdyż istotną część zajmowały w nim różnego rodzaju konkordancje, repertoria, florilegia, brakowało natomiast najważniejszych zbiorów prawa kanonicznego czy większości XIII-wiecznych komentarzy do Dekretałów.

Najwcześniej trafiły do biblioteki Piotra Wolframa kodeksy z tekstami prawniczymi proweniencji bolońskiej (BJ 372, BJ 344, BJ 395 i BKapKr. 94). Nie wiadomo dokładnie, kiedy Wolfram nabył boloński rękopis z komentarzem Gwidona de Baysio do Liber Sextus, spisany pod koniec XIV w. (BJ 372) ${ }^{19}$. Jak wskazuje nota celna, przyjechał z nim na studia do Padwy w 1411 r., dlatego można przypuszczać, że kupił go podczas swojego pobytu w Bolonii w 1409 r. Później być może pozbył się tego kodeksu, gdyż w 1418 r. na studia do Padwy pojechał z nim kanonik gnieźnieński Jakub ${ }^{20}$. Pozostałe trzy rękopisy zdobył Wolfram w czasie studiów w Bolonii w 1413 r. ${ }^{21}$ Rękopis BJ 395 spisany na

${ }^{16}$ Zob. I. Malinowska-Kwiatkowska, I manoscritti giuridici, s. 161-165; J.D. Janocki, Specimen catalogi codicum manuscriptorum bibliothecae Zaluscianae, Dresdae 1752, s. 74; M. Zwiercan, Piotr Wolfram, s. 405 n. Biblioteka Piotra Wolframa będzie przedmiotem oddzielnego artykułu.

${ }^{17}$ Rkps BJ 519 pozbawiony jest not własnościowych, papier datowany jest na 1413 r. Zdaniem M. Kowalczyk jego pierwsza część, zawierająca Partitiones oratoriae Cycerona emendowane w Konstancji przez Dominika Baiardiego z Fermo, została spisana ok. 1414 r. we Włoszech (k. 1r-9v), a druga (k. 11r-170r) ok. 1420 r. w Krakowie; Catalogus codicum manuscriptorum medii aevi Latinorum qui in Bibliotheca Jagellonica Cracoviae asservantur, t. 3, red. M. Kowalczyk i in., Wratislaviae 1984 (1985), s. 241; J. Słowiński oparł swoją hipotezę na fakcie, że wspomniany Dominik Baiardi w 1416 r. świadczył na dokumencie biskupa krakowskiego i kanclerza Królestwa Polskiego Wojciecha Jastrzębca. Badacz ten uznał, że osobą, która mogła sprowadzić Dominika Baiardiego do Krakowa, był Polak wykształcony we Włoszech, obecny na soborze w Konstancji, wykazujący zainteresowania humanistyczne, pozostający w dobrych relacjach z samym Jastrzębcem, a te warunki jednocześnie spełniał, jego zdaniem, Piotr Wolfram; tenże, Pismo humanistyczne w kręgu piętnastowiecznej Akademii Krakowskiej, St. Źródł., 35, 1994, s. 102-104. Rkps BJ 519 wymaga dalszych badań, niektóre znajdujące się w nim teksty nie zostały jeszcze poprawnie zidentyfikowane w najnowszym katalogu rękopisów średniowiecznych BJ, np. cztery listy Leonarda Bruniego (inc. „Solent, qui errati veniam petunt”, k. 85r-v, inc. „Oro te atque obsecro”, k. 116v, inc. „Et scribendo, et tacendo”, k. 119v-120r, inc. „Cum pro tanto honore”, k. 120r); zob. Catalogus codicum, t. 3, s. 208 n., 224 n.; L. Gualdo Rosa, Introduzione, w: Censimento dei codici dell'epistolario di Leonardo Bruni, t. 1: Manoscritti delle biblioteche non italiane, red. L. Gualdo Rosa, Roma 1993, s. XII.

${ }^{18}$ KDWlkp., t. 5, wyd. F. Piekosiński, Poznań 1908, nr 435; M. Czyżak, „,Volens de bonis et rebus suis sibi a Deo collatis anime sue saluti providere”. Testamenty kanoników i wikariuszy gnieźnieńskich w pierwszej połowie XV wieku, Rocz. Hist., 76, 2010, s. 106.

19 Catalogus codicum manuscriptorum medii aevi Latinorum qui in Bibliotheca Jagellonica Cracoviae asservantur, t. 2 , red. M. Kowalczyk, Wratislaviae 1982, s. 126 n.

20 Tamże; L. Gargan, L'enigmatico „,conduxit”. Libri e dogana a Padova fra Tre e Quattrocento, „Quaderni per la Storia dell'Università di Padova", 16, 1983, s. 24, nr 9; M. Zwiercan, I manoscritti medievali bolognesi della Biblioteca Jagellonica, w: Commentationes historicae Almae Matri studiorum Bononiensi novem saecula feliciter celebranti ab Universitate Iagellonica Cracoviensi oblatae, red. S. Cynarski, Warszawa-Kraków 1988, s. 80 n.

${ }^{21}$ Świadczą o tym znajdujące się na tych rękopisach noty: „Liber repertorium diversorum domini Petri Fabiani de Wolfram archidiaconi Cracoviensis, licenciati in decretis in Studio Bononiensi. Anno Domini 1413 ibidem comparatus”, BJ 395, k. 1r; „Collecta per dominum Petrum de Wolfram in Bononia licenciatum in decretis anno et cetera M CCC XIII”, BJ 344, k. Ir; „Repertorium super corpus Iuris copiosum scriptum d. Johannis de Calderini Bononie 1413 per Petrum Fabianum 
papierze datowanym na ok. 1411 r. zawiera komentarz z indeksem alfabetycznym do Speculum iudiciale Guillaume'a Duranda (k. 6v-33v), słowniczek terminów prawniczych z indeksem (k. 35v-55r), traktat dotyczący różnic między grzechem śmiertelnym i lekkim (k. 55r-56r), konkordancję do Dekretałów (k. 60r-135r), konkordancje do Biblii i dekretów (k. 140r-190v) oraz indeks do Apparatus Innocentego IV - Repertorium super Innocencio (k. 194r-273) ${ }^{22}$. W datowanym na początek XV w. rękopisie BKapKr. 94 znajduje się natomiast Repertorium sive vocabularium utriusque iuris Jana Calderiniego (k. 1r-313r) ${ }^{23}$. Najbogatszy, jeśli chodzi o liczbę tekstów i ich różnorodność, jest rękopis BJ 344, spisany przez kilku skrybów na papierze datowanym na lata 1404-1411. W 1413 r. została skopiowana Tabula auctoritatum et sententiarum Bibliae cum concordantiis decretorum et decretalium Jana Calderiniego (k. 1r-56v) ${ }^{24}$ oraz Questio disputata de laico homicida qui se promoveri fecit ad sacerdotium Piotra z Ancarano (k. 211r-221r) ${ }^{25}$. Oprócz tego kodeks ten zawiera glosę do komentarza Franciszka Zabarelli do Liber Sextus (k. 60r-77r), Speculum manuale sacerdotum Hermanna von Hildesche (k. 77v-80v), alfabetyczne konkordancje do De civitate Dei św. Augustyna (k. 81r-140v) i do Policraticusa Jana z Salisbury (k. 141r-183v), traktat Jana Calderiniego De interdicto ecclesiastico (k. 198r-210v), formułę rozgrzeszenia in articulo mortis (k. 221r), rezerwaty papieskie i biskupie dotyczące sakramentu pokuty (k. 221r-222r), zbiór brokard Damasusa (k. 223r-238v), pięć mów uniwersyteckich bolońskich, w tym jedną z 1413 r. (k. 239r-242v) ${ }^{26}$, fragment Secretum secretorum Pseudo-Arystotelesa (k. 243r-246v), a także list Petrarki ze zbioru Liber sine nomine ${ }^{27}$.

W 1414 r. Piotr Wolfram kupił komentarz Grzegorza Wielkiego do Księgi Hioba, Liber moralium in Job (Moralia), znajdujący się w dwóch kodeksach przepisanych w 1392 r. w Czechach (BJ 1350 i BJ 1352) ${ }^{28}$. Kazania Wolframa zachowane w rękopisie BJ 2459 świadczą, że dzieło to stanowiło dla niego obszerny zbiór cytatów ${ }^{29}$. Rękopis BJ 1596 według noty na przedniej karcie pergaminowej został spisany w 1415 r. ${ }^{30}$ Znajdują się w nim jednak również mowy i kazania soborowe z 1416 i 1417 r. ${ }^{31}$

de Wolfram licentiatum in decretis ibidem Bononie”, BKapKr. 94, k. Ir; Catalogus codicum, t. 2, s. 34, 175; I. Polkowski, Katalog rękopisów kapitulnych katedry krakowskiej, Kraków 1884, s. 80.

22 Catalogus codicum, t. 2, s. 172-175.

${ }^{23}$ I. Polkowski, Katalog rękopisów, s. 80.

${ }^{24}$ Świadczy o tym kolofon: „18 die Februarii anno M CCCC XIII per Nycolaum Spreet de Hamborch”, BJ 344, k. 56v; Catalogus codicum, t. 2, s. 29.

${ }^{25}$ W kolofonie jest data: „M CCCC XII die XXIII Aprilis”, k. 221r; Catalogus codicum, t. 2, s. 31.

${ }^{26}$ Mowa z okazji doktoratu obojga praw Battisty d'Argile (9 V 1413), inc. „In nomine Domini nostri Ihesu Christi. Amen. In me omnis gracia vite et virtutis", BJ 344, k. 241r-242r; zob. Catalogus codicum, t. 2, s. 32; Liber secretus iuris caesarei dell'università di Bologna, t. 1: 1378-1420, wyd. A. Sorbelli, Bologna 1938, s. 210.

27 Inc. „Ve populo tuo, Christo Ihesu”, BJ 344, k. 247r-v; niezidentyfikowany w katalogu rękopisów średniowiecznych BJ. Szczegółowy opis rękopisu i wykaz tekstów zob. Catalogus codicum, t. 2, s. 29-34. List ten w Liber sine nomine występuje jako dwunasty; zob. F. Petrarca, Liber sine nomine, wyd. G. Cascio, Firenze 2015, s. 110-116. Chciałabym wyrazić głęboką wdzięczność prof. Halinie Manikowskiej (IH PAN) za pomoc w identyfikacji tego listu.

${ }_{28}$ Zob. J. Zathey, Biblioteka Jagiellońska w latach 1364-1492, w: J. Zathey, A. Lewicka-Kamińska, L. Hajdukiewicz, Historia Biblioteki Jagiellońskiej, t. 1: 1364-1775, red. I. Zarębski, Kraków 1966, s. 81; Catalogus codicum manuscriptorum medii aevi Latinorum qui in Bibliotheca Jagellonica Cracoviae asservantur, t. 8, wyd. M. Kowalczyk i in., Cracoviae 2004, s. 384-386, 392-394.

29 Piotr Wolfram w kazaniu (inc. „Quodcumque dixerit vobis facite”, BJ 2459, k. 191r-193v) wykorzystał następujący cytat z Moralia Grzegorza Wielkiego: „Oboedientia namque sola virtus est ut dicit Gregorius XII ${ }^{\circ}$ Moralium” („Posłuszeństwo bowiem jest samą cnotą, jak mówi Grzegorz w rozdziale XII Moraliów" - thum. A.H.), BJ 2459, k. 192v; zob. Moralia sancti Gregorii pape super Job, Venetiis, wyd. Andreas Torresanus, 11 IV 1496, 2 , k. 324r (ks. 35, rozdz. 12). O wykorzystywaniu cytatów z Grzegorza Wielkiego w kazaniach w epoce średniowiecza zob. K. Bracha, Nauczanie kaznodziejskie w Polsce późnego średniowiecza. „, Sermones dominicales et festivales” z tzw. kolekcji Piotra z Mitosławia, Kielce 2007, s. 98-100.

30 „Liber domini Petri de Wolfram [...] scriptus in Constancia tempore generalis Concilij, 1415”, BJ 1596, k. IIr; zob. W. Wisłocki, Katalog rękopisów Biblioteki Uniwersytetu Jagiellońskiego, cz. 1, Kraków 1877, s. 386.

${ }^{11}$ Na przykład kazanie Maurycego Rvački, inc. „Johannis 16 originative et in officio misse transumptive”, BJ 1596, k. 186v-190v (datowane na $17 \mathrm{~V} \mathrm{1416),} \mathrm{kazanie} \mathrm{Bernarda} \mathrm{de} \mathrm{la} \mathrm{Planche,} \mathrm{inc.} \mathrm{„Johannis} 16$ et in ewangelio hodierno patres prelati”, BJ 1596, k. 190v-194r (10 V 1416), kazania Alessio di Siregno inc. ,ad Romanos $15^{\circ}$ capitulo et in epistola dominice currentis”, BJ 1596, k. 201r-204r (7 XII 1416 lub 7 XII 1417) oraz inc. „Mathei 17 et in ewangelio hodierno secundum sentenciam”, BJ 1596, k. 204v-207v (14 III 1416), mowa Poggia Braccioliniego, inc. „Vellem patres reverendissimi tantum 
Oprócz tego kodeks ten zawiera traktat antyheretycki Álvara Pelayo Collirium fidei adversus hereses novas (k. 221r-288r), a także Compendium moralium notabilium (k. 10r-178v) - zbiór cytatów z Biblii, autorów starożytnych (głównie łacińskich), dzieł filozoficznych i prawniczych ułożonych tematycznie przez padewskiego sędziego i pisarza Jeremiasza z Montagnone (zm. ok. 1321) ${ }^{32}$. Wspomniane florilegium było znane w środowisku krakowskim, posiadali je Maciej z Koła (rękopis Biblioteki Kapituły Katedralnej w Gnieźnie 55, spisany ok. 1408) i Paweł Włodkowic (rękopis BJ 700, spisany w 1419 r.) ${ }^{33}$.

Wolfram posiadał także rękopis BCzart. 2008, spisany w większości w 1420 r. w Gnieźnie, zawierający trzy traktaty Jana Gersona (s. 166-174), dekret Gentilisa de Monteflorum, legata papieskiego na Polskę i Węgry, o elekcji kanonicznej z 1309 r. (s. 161-165), Distinctiones Mikołaja Gorry (s. 185-416), Liber de miseria condicionis humanae Innocentego III (s. 177-183) oraz listy Piotra z Blois (s. 1-160), z których korzystał później przy układaniu własnych kazań ${ }^{34}$. Niezachowany rękopis Wolframa przechowywany niegdyś w Bibliotece Załuskich według katalogu Jana Daniela Janockiego został spisany w 1423 r. i zawierał dzieła Cycerona: Brutus, De oratore, Topika i Partitiones oratoriae ${ }^{35}$. Ostatnie dwa kodeksy nie mogą być brane pod uwagę jako źródło, z którego Wolfram czerpał cytaty do listów pisanych z Konstancji, ale uzupełniają one obraz jego formacji intelektualnej i warsztatu pisarskiego.

Listy Piotra Wolframa (8) znane są jedynie z kopii zachowanych w XV-wiecznym kodeksie (BPAU/ PAN 6641), który przez długi czas był własnością włocławskiej kapituły katedralnej (o czym świadczy nota na przedniej wyklejce spisana w XVII w.), a później należał do ks. Jana Fijałka, który przekazał go Bibliotece $\mathrm{PAU}^{36}$. Na początku kodeksu znajduje się blok tekstów prawniczych, ale występują one również w dalszych częściach między listami i mowami: Repertorium supra iure canonico (k. 1r-71v) przypisane Piotrowi z Perugii (zapewne chodzi o Pietra degli Ubaldi, brata słynnego Balda) ${ }^{37}$, fragment

virtutis", BJ 1596, k. 179r-184r (lato albo wczesna jesień 1417); zob. C. Nighman, P. Stump, A Bibliographical Register of the Sermons and Other Orations Delivered at the Council of Constance (1414-1418), <https://bibsocamer.org/BibSite/ Nighman-Stump/3-Main-Sermon-Register.pdf> [dostęp: 5.05.2020], s. 33, 144, 162, 209, 247.

32 Obecna foliacja rękopisu różni się od podanej przez W. Wisłockiego, Katalog rękopisów, s. 386; G. Milan, Geremia da Montagnone, w: Dizionario Biografico degli Italiani, t. 53, Roma 2000, s. 400-403; R.G. Witt, Sulle tracce degli antichi. Padova, Firenze e le origini dell'umanesimo, thum. D. De Rosa, wprow. G. Pedullà, Roma 2005, s. 116 n.; J.B. Korolec, Jeremiasza de Montagnone „Compendium moralium notabilium”, „Materiały do Historii Filozofii Średniowiecznej”, 5 (16), 1972, s. 13-21.

33 J.B. Korolec, Jeremiasza de Montagnone, s. 13 n.; Catalogus codicum manuscriptorum medii aevi Latinorum qui in Bibliotheca Jagellonica Cracoviae asservantur, t. 5, red. M. Kowalczyk i in., Wratislaviae 1993, s. 90 n.; J. Rył, Katalog rękopisów Biblioteki Katedralnej w Gnieźnie, „Archiwa, Biblioteki i Muzea Kościelne”, 45, 1982, s. 50 n.

${ }^{34}$ W. Szelińska, Piotr Wolfram, profesor Uniwersytetu Krakowskiego i jego nieznany rękopis, „Rocznik Naukowo-Dydaktyczny. Prace Historyczne [Wyższej Szkoły Pedagogicznej im. KEN w Krakowie]”, 59, 1977, nr 8, s. 49-58. Cytaty z listu Piotra z Blois napisanego z okazji elekcji Renauda de Mouçon na biskupa Chartres (1183) Wolfram wykorzystał w swoim kazaniu z okazji elekcji Jana Pelli na biskupa włocławskiego w 1421 r. (inc. „Ite et vos in vineam meam”, BJ 2459, k. 185r-188r): „hec omnia ut inquit Petrus Blesensis a mente futuri episcopi convenit exulare”, tamże, k. 187r (,te wszystkie [rzeczy], jak powiada Piotr z Blois, należy oddalić z umysłu przyszłego biskupa" - tłum. A.H.). W przywołanym przez Wolframa fragmencie listu Piotra z Blois jest mowa o konieczności uwolnienia się przyszłego biskupa od żądz cielesnych; zob. BCzart. 2008, s. 32; Petri Blesensis Bathoniensis archidiaconi Opera omnia, t. 1: Epistolae, wyd. A. Giles, Oxonii 1847, s. 53 (list XV); czy kolejny obszerny cytat w tymże kazaniu zawierający zalecenia dla przyszłego biskupa: „omni antiqua vanitate postposita [...] Exhibe te Johannem incestuosis Jehu et Mathathiam apostatis, fornicantibus Finees, Heliam idolatris, mencientibus Petrum quod [sic!] blasphemantibus Paulum negociantibus Christum” (,porzuciwszy wszelką dawną próżność [...] okaż się kazirodcom niczym Jan apostatom niczym Jehum i Matatiasz, uprawiającym nierząd niczym Pinchas, bałwochwalcom niczym Eliasz, kłamcom niczym Piotr, bluźniercom niczym Paweł, kupczącym niczym Chrystus” - tłum. A.H.), BJ 2459, k. 187v; zob. BCzart. 2008, s. 33; Petri Blesensis, s. 55. O Renaudzie de Mouçon zob. Cartulaire de Notre-Dame de Chartres, t. 1, wyd. E. de Lépinois, L. Merlet, Chartres 1862, s. XXXVIII.

35 J.D. Janocki, Specimen catalogi, s. 74.

${ }^{36}$ E. Knapek, Rękopisy średniowieczne w zbiorach Biblioteki Naukowej PAU i PAN w Krakowie, „Rocznik Biblioteki PAU i PAN w Krakowie", 57, 2012, s. 38.

37 Autorem większości dzieł prawniczych, przy których w rękopisach występowało imię Piotra z Perugii („Petrus de Perusio”), zdaniem badaczy był Pietro degli Ubaldi (zm. 1412), wykładający w Perugii od 1364 r., a nie Pietro da Perugia, wykładowca na uniwersytecie w Vercelli (1340-1343) i adwokat konsystorza w Kurii Rzymskiej (od 1343); P. Rosso, Pietro da 
niezidentyfikowanego traktatu (k. 72r-74r), Tabula auctoritatum et sententiarum Bibliae cum concordantiis decretorum et decretalium Jana Calderiniego (k. 75r-127v), Concordancie glosarum contrarium in iure canonico (k. 129v-149r), Opinio Ostiensis Pawła Włodkowica (k. 150v-154r), fragment konkordancji do prawa kanonicznego (k. 435v). Kolejną część stanowią kopiariusze korespondencji głównie z lat 1416-1464: m.in. Macieja z Raciąża (k. 128v-129r), kopie listów związanych z soborem w Konstancji oraz listów z czasów Mikołaja V i Piusa II (k. 154r-177r), wśród których znajdują się listy Piotra Wolframa (k. 167v-169v, 171r-171v, 173v-174v, 176v), traktat antyhusycki (inc. „Audite celi, que loquor", k. 177v-183v), kazania i mowy uniwersyteckie, m.in. Stanisława ze Skalbmierza, Jana Elgota, Mateusza z Krakowa, Pawła z Zatora (w większości zgrupowane obok siebie na k. 186r-222v), następnie znajdują się kopie listów Zbigniewa Oleśnickiego i Władysława Jagiełły (k. 224v), formularz czynności prawnych z kancelarii Jana Elgota wikariusza generalnego krakowskiego (1437-1452), a potem pisma związane z diecezją włocławską - Macieja z Raciąża wikariusza generalnego in spiritualibus biskupa włocławskiego (k. 234v), biskupa włocławskiego Jana Pelli w sprawie wizytacji diecezji w 1424 r. (k. 235r), dekret Jana Pelli z 1424 r. zwołujący synod diecezjalny (k. 235r) ${ }^{38}$. Znajdujące się w tym kodeksie listy Wolframa zostały wydane w XIX w. przez Anatola Lewickiego ${ }^{39}$.

$\mathrm{Z}$ nich na szczególną uwagę, jeśli chodzi o cytaty, które stanowiły przesłankę do rozważań na temat humanistycznych zainteresowań Piotra Wolframa, zasługują dwa listy napisane z Konstancji do biskupa krakowskiego i kanclerza Królestwa Polskiego Wojciecha Jastrzębca (inc. „Scribitis michi, pater mi et domine, putatisque”) datowany na 1418 r. i do nieznanego prałata (inc. „Pater mi et domine. Putabam iuxta sentenciam salvatoris prophetam in patriam minime reputari") datowany na pierwszy kwartał $1418 \mathrm{r}^{40}$

W pierwszym ze wspomnianych listów Piotr Wolfram uskarżał się na niesprecyzowane bliżej krzywdy doznane od kancelarii królewskiej oraz od Piotra syna Bolesty z Pieskowic, który miał pisać do króla oczerniające go listy. Tenże Piotr z Pieskowic (zm. 1430), krewny Wojciecha Jastrzębca, prepozyt łęczycki i kanonik gnieźnieński, wchodził w skład poselstwa polskiego na sobór w Konstancji; wiadomo o nim, że wikłał się w liczne spory, zabiegając o beneficja ${ }^{41}$. Zapewne rywalizował z Wolframem o beneficja oraz o względy na dworze. W liście tym Wolfram powoływał się na swoją wierną służbę poza granicami kraju i w tym kontekście przywoływał przykład Sokratesa na wygnaniu:

Verumquidem, si non obstante iusticia quam offero sue serenitati videretur expediens me extra regnum suum demorari, in hoc sui solius et nullius alterius de regno necessario esset parendum voluntati nec propterea minus sibi et regno fideliter servire, nam ubicunque fuero, me natum in Polonia ut spero ex famosis parentibus non negabo; licet legerim de Socrate, qui cum citra demerita passus fuisset exilium, requisitus a quodam cuias esset fertur respondisse: mundanus sum, qui nobilissimus Attheniensis civis erat. Legi propero alias annales, veterum historias, quod multos, sicut narrat laureatissimus poetarum Franciscus patriarcha, exilium honestavit multos, acrior aliqua fortune vis atque in memoria notos fecit et illustres; propter quod, si exulari opporteret, mundus est michi patria ${ }^{42}$, sicut et Socrati; rursus curia Romana multis eciam maioribus

Perugia, w: Dizionario Biografico degli Italiani, t. 83, Roma 2015, s. 535 n.; G. Ermini, Storia dell'università di Perugia, t. 1, Firenze 1971, s. 164 n.

${ }^{38}$ Katalog rękopisów Biblioteki Naukowej PAU i PAN w Krakowie. Sygnatury 6551-6880, oprac. E. Danowska, E. Knapek, Kraków 2008, s. 86-93; E. Knapek, Rękopisy średniowieczne, s. 38.

${ }^{39}$ C. epist. XV, t. 2: 1382-1442, oprac. A. Lewicki, Kraków 1891, nr 75, s. 89, nr 76, s. 90-92, nr 80, s. 97 n., nr 82, s. 100 n., nr 87 , s. 107 , nr 90, s. $110-112$, nr 91, s. 112-114, nr 97, s. 125-127.

${ }^{40}$ Tamże, nr 80 i 82, s. 91 n., 100 n. Na temat Wojciecha Jastrzębca zob. G. Lichończak-Nurek, Wojciech herbu Jastrzębiec, s. 63; K. Ożóg, Biskupa Wojciecha Jastrzębca paterna sollicitudo o Kościót krakowski. Statuty synodalne z roku 1420, w: Wojciech Jastrzębiec - w stużbie monarchii i Kościoła, red. B. Czwojdrak, F. Kiryk, J. Sperka, Katowice 2018, s. $145-159$.

${ }^{41}$ Z.H. Nowak, Piotr Boleścic z Pieskowic, w: PSB, t. 26, s. 414 n.; A. Kowalska-Pietrzak, Prałaci i kanonicy kapituły tęczyckiej do schyłku XV wieku, Łódź 2004, s. 51-53.

${ }^{42} \mathrm{U}$ Petrarki passus ten brzmi: „Multos exilium honestavit, multos acrior aliqua fortune vis atque iniuria notos reddidit et illustres [...]. Interrogatus Socrates cuias esset, »mundanus, inquit, sum«. Vere socraticum responsum; Atheniensem se alius respondisset: Socrati autem patria omnium mundus erat"; Petrarka, De remediis utriusque fortunae, II 67 (De exilio), wyd.: Pétrarque, Les remèdes aux deux fortunes, t. 1: Texte et traduction, wyd. Ch. Carraud, Grenoble 2002, s. 826-828. 
me est domicilium, ad quam fere omnes citra exilium confluxerunt. Plura propter occupaciones diversas agendorum et presertim lecturarum in sessione isto mane scribere non potui [podkr. A.H. $]^{43}$.

Po pierwsze, wyjaśnienia wymaga źródło tego cytatu. Ze względu na użyte przez Wolframa sformułowanie „Legi propero alias annales, veterum historias” Nice Contieri uważała, że zaczerpnął on cytat z De viris illustribus lub z Rerum memorandarum libri Petrarki, w których też jest mowa o wygnaniu słynnych osób starożytnych (ale nie Sokratesa) ${ }^{44}$. W ujęciu badaczki nie byłby to zatem cytat, tylko wykorzystanie argumentów zaczerpniętych od Petrarki. Określenia annales i historias użyte przez Wolframa nie muszą wcale przesądzać, że korzystał on z dzieła, które obecnie zaliczylibyśmy do kategorii historiograficznych. Sama obecność w przywoływanej pracy przykładów zaczerpniętych z dziejów starożytnych mogła wystarczyć, by użyć takiego określenia ${ }^{45}$. Sformułowanie veterum historias może stanowić też zwrot czysto retoryczny, wskazywać na odwołanie do autorytetu - przez kategorię dawności ${ }^{46}$.

Właściwe źródło tego cytatu wskazał Juliusz Domański - jest to inne dzieło Petrarki, De remediis utriusque fortunae, ks. 2, rozdz. 67 (De exilio) ${ }^{47}$. Wolfram dość wiernie zacytował dwa krótkie passusy $\mathrm{z}$ tego rozdziału, zmieniając ich kolejność w stosunku do wspomnianego dzieła i nieco je modyfikując (zob. przyp. 42). Zadeklarował gotowość służenia królowi nawet na wygnaniu, dlatego że nadal będzie się czuć Polakiem, mimo przykładu Sokratesa (zaczerpniętego z De remediis utriusque fortunae Petrarki), który po wygnaniu z Aten odpowiedział, że czuje się obywatelem świata. Dalej Wolfram powołał się na autorytet Petrarki, przypominając, że wielu ludziom wygnanie przyniosło zaszczyty. Jak wskazał J. Domański, Wolfram nie rozwinął szerzej wątku wygnania obecnego u pisarzy starożytnych Cycerona i Seneki, a także we wczesnym humanizmie włoskim, tylko zręcznie wplótł we własny tekst przykład i cytat zaczerpnięty od Petrarki ${ }^{48}$.

Twórczość Petrarki mieści się na pograniczu dwóch epok, przy czym De remediis utriusque fortunae nosi charakter bardziej „średniowieczny” ze względu na przesłanie moralne, mimo że pod względem formy nawiązuje do dialogu sokratejskiego ${ }^{49}$.

${ }^{43}$ C. epist. XV, t. 2, nr 80, s. 91 n.: „Przecież, jeśli mimo sprawiedliwego postępowania, które ofiarowuję najjaśniejszemu panu, uznał za słuszne wysłać mnie, abym przebywał poza jego królestwem, w czym należało być posłusznym jego woli i bynajmniej nie służyłem dlatego mniej wiernie jemu i królestwu. Gdziekolwiek bowiem będę, nie zaprzeczę, że narodziłem się w Polsce, jak mam nadzieję, ze sławetnych rodziców. Czytałem wprawdzie o Sokratesie, który, gdy przebywał na wygnaniu i został zapytany, za kogo się uważa, odpowiedział: jestem obywatelem świata, który był szlachetnym obywatelem ateńskim. Przeczytałem pospiesznie inne roczniki, stare historie [i dowiedziałem się - A.H.], że wielu, jak powiada najznakomitszy z poetów Franciszek Patriarcha, wygnanie doprowadziło do zaszczytów, innych moc fortuny uczyniła mężniejszymi oraz godnymi pamięci i sławnymi. Dlatego, jeśli będę zmuszony przebywać na wygnaniu, świat będzie dla mnie ojczyzną, jak dla Sokratesa. Po powrocie Kuria Rzymska, do której prawie wszyscy na wygnaniu napływają, będzie dla mnie domem, jak również dla wielu większych ode mnie. Nie mogłem więcej napisać tego poranka ze względu na różne zajęcia związane ze sprawami i publicznymi odczytami na sesji” - tłum. A.H.

${ }^{44}$ N. Contieri, La fortuna del Petrarca in Polonia, s. $148 \mathrm{n}$.

45 Petrarka bywał określany nie tylko jako poeta, ale też jako historyk, np. przy okazji koronacji wieńcem laurowym na Kapitolu w 1341 r.; zob. L. Secchi Tarugi, La dimensione europea della cultura di Francesco Petrarca, w: Petrarka a jedność kultury europejskiej. Materiaty międzynarodowego zjazdu, Warszawa, 27-29 V 2004 / Petrarca e l'unità della cultura europea. Atti del convegno internazionale, red. M. Febbo, P. Salwa, Warszawa 2005, s. 17.

${ }^{46}$ H. Lausberg, Handbook of Literary Rhetoric. A Foundation for Literary Study, thum. D.F. Orton, R.D. Anderson, Leiden-Boston 1998, s. 544 (tłum. pol.: Retoryka literacka. Podstawy wiedzy o literaturze, thum., oprac. i wstęp A. Gorzkowski, Bydgoszcz 2002).

47 Zob. J. Domański, Poczatki humanizmu, Wrocław 1982, s. 56, i nowsza, zmieniona wersja: Scholastyka i początki humanizmu, s. 77-79.

${ }^{48} \mathrm{~W}$ przypadku wspomnianego listu Wolframa nie widać pogłębionej refleksji dotyczącej wygnania tak jak u Petrarki, identyfikującego całe swoje życie z wygnaniem, rozumiejącego to zagadnienie szerzej niż tylko jako stan prawny, ale przede wszystkim jako stan egzystencjalny, metaforę ludzkiego życia; zob. J. Domański, Początki humanizmu, s. 56; R. Hexter, Ovid and the Medieval Exilic Imaginary, w: Writing Exile. The Discourse of Displacement in Greco-Roman Antiquity and Beyond, red. J.F. Gaertner, Leiden-Boston 2007, s. 155-172; L.E. Hooper, Exile and Petrarch's Reinvention of Authorship, „Renaissance Quarterly”, 69, 2016, nr 4, s. 1217-1256.

49 J. Pelán, Il „De remediis” di Francesco Petrarca e la sua fortuna in Boemia, w: Petrarka a jedność kultury europejskiej, s. $340 \mathrm{n}$. 
Odrębny problem stanowi identyfikacja źródła, z którego Wolfram przejął ten cytat: czy bezpośrednio z dzieła Petrarki, czy z jakiegoś florilegium ${ }^{50}$. Zacytowanie $\mathrm{w}$ zmienionej kolejności oddalonych od siebie nieco passusów i lekkie sparafrazowanie może wskazywać, że Wolfram czytał właśnie De remediis utriusque fortunae, ale cytował $\mathrm{z}$ pamięci. Wydaje się, że dzieło to, napisane $\mathrm{w}$ formie dialogu, stanowiące rodzaj obszernej encyklopedii moralnej, ilustrowanej przykładami z historii starożytnej i sentencjami zaczerpniętymi od poetów oraz filozofów łacińskich ${ }^{51}$, mogło odpowiadać zapotrzebowaniom Wolframa, szukającego łatwych do odnalezienia cytatów (na co wskazuje zawartość jego biblioteki). W przypadku cytatu użytego przez Wolframa sprawa była dość prosta - wystarczyło odnaleźć wątek wygnania po tytule rozdziału. Być może zaczerpnął ten cytat od innego autora, ale jest to kwestia trudna do rozstrzygnięcia.

Fizyczna obecność De remediis utriusque fortunae w Krakowie jest poświadczona ok. 1430 r., kiedy to Piotr z Telcz przepisał jeden $\mathrm{z}$ najstarszych zachowanych krakowskich rękopisów z tym tekstem, BJ 722, którego właścicielem stał się krakowski profesor teologii Mikołaj Kozłowski (zm. 1443) ${ }^{52}$. Należy sądzić, że już wcześniej został przywieziony do Krakowa egzemplarz De remediis utriusque fortunae, który mógł być podstawą kopii sporządzonej dla Kozłowskiego.

Można wskazać kilka miejsc, gdzie Wolfram mógł się zetknąć z dziełami Petrarki. Mogło to nastąpić podczas studiów w Pradze (1408), gdzie na recepcji dzieł Petrarki (ograniczonej do łacińskich dzieł filozoficznych, jak De remediis utriusque fortunae i De vita solitaria) zaważyła wizyta poety w 1356 r. na dworze cesarza Karola IV oraz kontakty listowne utrzymywane z nim przez Jana ze Środy (zm. 1380), kanclerza Karola IV i biskupa Ołomuńca (od 1364) ${ }^{53}$. Znaczenie miał także fakt, że Wolfram studiował w Padwie (1411), gdzie kwitły tradycje literackie zaszczepione przez Petrarkę, który ostatnie lata życia spędził w willi w Arquà niedaleko Padwy ${ }^{54}$. Równie ważną rolę mógł odegrać w tym względzie sobór w Konstancji. Należący do jego czołowych uczestników kardynał florencki i słynny kanonista Franciszek Zabarella (zm. 1417), z którym polska delegacja pozostawała w dobrych kontaktach (pod jego kierunkiem studiowali w Padwie Paweł Włodkowic oraz Andrzej Łaskarzyc), cenił Petrarkę, posiadał w swojej bibliotece De remediis utriusque fortunae obok innych

${ }^{50} \mathrm{O}$ cytatach pośrednich zob. W. Pawlak, „O pewnym sposobie [...]”, s. 48 n.

${ }^{51}$ J. Pelán, Il „De remediis” di Francesco Petrarca, s. 341.

${ }^{52}$ M. Zwiercan, Kozłowski Mikołaj, w: PSB, t. 15, Wrocław 1970, s. 26-28; M. Kowalczyk, Z badań nad życiem i biblioteka Mikołaja Kozłowskiego, „Biuletyn Biblioteki Jagiellońskiej”, 22, 1972, s. 20; J. Zathey, Biblioteka Jagiellońska, s. 74. Jak się wydaje, De remediis utriusque fortunae służyło też Mikołajowi Kozłowskiemu jako zbiór egzemplów i cytatów, o czym świadczą noty marginalne przypisywane Kozłowskiemu przez M. Kowalczyk, takie jak „Exemplum Socratis” (k. 124r), „Exemplum Catonis”, (k. 279r); zob. Catalogus codicum, t. 5, s. 190 n. W. Szelińska wykazała, że w kolofonie na końcu tego kodeksu (zawierającego także dzieła Seneki) znajduje się rozbite na części i wplecione w kolofon imię i nazwisko Mikołaja Kozłowskiego jako nabywcy kodeksu obok imienia skryby Piotra z Telcz. Wspomniana badaczka zwróciła uwagę, że sam tekst został spisany minuskułą gotycką o kroju rzadko spotykanym wówczas w Polsce, ale identyfikując jako miejsce pochodzenia Piotra miejscowość Telcze (Cielce) nad dopływem Styru, nie potrafiła wyjaśnić tego faktu. Wydaje się, że kopistę należy utożsamić z Piotrem synem Jana z Telcz (Telč) na Morawach (co thumaczyłoby także pewną odmienność kroju jego pisma), który wpisał się na Uniwersytet Krakowski w 1425 r.; taż, Biblioteki profesorów Uniwersytetu Krakowskiego w XV i początkach XVI wieku, Wrocław 1966, s. 48 n.; zob. Metryka Uniwersytetu Krakowskiego z lat 1400-1508, t. 1, wyd. A. Gąsiorowski, T. Jurek, I. Skierska, Kraków 2004, nr 25/058.

53 J. Pelán, Il „De remediis” di Francesco Petrarca, s. 339-344; J. Nechutová, Die lateinische Literatur des Mittelalters in Böhmen, tłum. H. Boková, V. Bok, Köln-Weimar-Wien 2007, s. 176-183; T. Kircher, Petrarch and Humanists, w: The Cambridge Companion to Petrarch, red. A.R. Ascoli, U. Falkeid, Cambridge 2015, s. 185. Na temat Jana ze Środy zob. H.J. Rieckenberg, Johann von Neumarkt, w: Neue Deutsche Biographie, t. 10, Berlin 1974, s. 563 n.

${ }^{54}$ O dużym i utrzymującym się znaczeniu tradycji intelektualnych związanych z Petrarką (szczególnie z jego dziełami filozoficznymi) w środowisku uniwersyteckim padewskim w pierwszych dekadach XV w. świadczy fakt, że przybyli zza Alp studenci przepisywali lub kupowali tam rękopisy z dziełami Petrarki. Mikołaj z Kuzy, studiujący w Padwie w latach 1417-1423, zdobył tam De vita solitaria, De remediis utriusque fortunae, Rerum memorandarum libri, Secretum, Liber sine nomine, De otio religioso i De ignorantia Petrarki; G. Billanovich, Gli inizi della fortuna di Francesco Petrarca, Roma 1947, s. 93-95; zob. też A. Sottili, Studenti tedeschi a Padova e le opere del Petrarca in Germania durante il Quattrocento, w: tenże, Scritti petrarcheschi, red. F. Della Schiava, A. De Patto, C.M. Monti, Roma-Padova 2015 , s. $36-56$. 
jego dzieł ${ }^{55}$. Mowy wygłaszane przez Zabarellę na soborze były chwalone również ze względu na niezwykłą elokwencję ${ }^{56}$.

Przebywając w Konstancji, Wolfram z łatwością mógł mieć dostęp do rękopisów z dziełami Petrarki. Sobór pełnił bowiem także rolę forum wymiany idei humanistycznych - szerokim echem odbiły się odkrycia dzieł autorów starożytnych dokonywane przez florenckiego humanistę obecnego na soborze, Poggia Braccioliniego, w czasie jego wypraw do pobliskich klasztorów, z których szczególnie ważnym, z punktu widzenia rozwoju nowej retoryki humanistycznej, było odnalezienie latem $1416 \mathrm{r}$. w klasztorze Sankt Gallen kodeksu zawierającego pełny tekst Institutio oratoria Kwintyliana (we wcześniejszych wiekach znane były tylko fragmenty). Jednocześnie sobór stanowił „składnicę książek” (od dzieł z zakresu teologii i prawa kanonicznego po teksty humanistów czy świeżo odkryte dzieła autorów starożytnych), które można było nabyć, skopiować samemu lub zlecić skopiowanie jednemu z wielu przebywających tam zawodowych skrybów ${ }^{57}$.

Użyty przez Wolframa zwrot „sicut narrat laureatissimus poetarum Franciscus patriarcha” skłaniał niektórych badaczy do daleko idących wniosków, że Polak znał poezje Petrarki ${ }^{58}$. Samo użycie takiego określenia nie jest wystarczającą przesłanką do tego rodzaju konkluzji, gdyż było to powszechnie stosowane określenie w rękopisach zawierających filozoficzne dzieła Petrarki, takie jak De remediis utriusque fortunae $e^{59}$.

Adresatem drugiego listu zawierającego kilka cytatów z autorów klasycznych był nieznany bliżej duchowny, który otrzymał jakąś kustodię, o którą ubiegał się Wolfram ${ }^{60}$. Autor składał gratulacje i przestrzegał odbiorcę przed zagrożeniami dla rozwoju duchowego związanymi z otrzymaniem bogatej prałatury. List ten stanowi w zasadzie zlepek cytatów - przytaczanych wiernie lub parafrazowanych, a także aluzji, co sprawia wrażenie, jakby Wolfram za pomocą erudycji starał się pokonać i zawstydzić swojego rywala. Autor mógł bowiem zakładać, że jego list będzie kopiowany.

Putabam iuxta sentenciam salvatoris prophetam in patria minime reputari ${ }^{61}$, vos vero nedum in Cafarnaum $^{62}$ sed et in propria patria miraculis et portentis patenter et mirabiliter coruscatis, tollentes, quod non posuistis $^{63}$ etc. [...]. Unde si vos, qui sedetis super ollas carnium ${ }^{64}$ etc., crescere, me autem, qui in confinio

55 G. Billanovich, Petrarca letterato, t. 1: Lo scrittoio di Petrarca, Roma 1947, s. 381; A. Sottili, La questione ciceroniana in una lettera di Francesco Zabarella a Francesco Petrarca, „Quaderni per la Storia dell’Università di Padova”, 6, 1973, s. 38; N. Contieri, La fortuna del Petrarca in Polonia, s. 147; T.E. Morrissey, Cardinal Zabarella and Nicholas of Cusa. From Community Authority to Consent of the Community, „Mitteilungen und Forschungsbeiträge der Cusanus-Gesellschaft", 17, 1986, s. 157. Na temat kontaktów Polaków z Zabarellą zob. J. Fijałek, Polonia apud Italos scholastica, s. 20-26; K. Pieradzka, Uniwersytet w stużbie państwa i soborów, w: Dzieje Uniwersytetu Jagiellońskiego, t. 1, s. 93, 95-98; D. Girgensohn, Studenti e tradizione delle opere di Francesco Zabarella nell'Europa Centrale, w: Studenti, università, città nella storia padovana. Atti del convegno, Padova 6-8 febbraio 1998, red. F. Piovan, L. Sitran Rea, Trieste 2001, s. 144; A. Niesiołowski, Paweł Włodkowic i jego doktryny na tle epoki (z okazji 500-lecia jego śmierci), w: S. Bełch, J. Domański, T. Graff, T. Jasudowicz, S. Krzyżanowski, A. Niesiołowski, K. Ożóg, S. Wielgus, Paweł Włodkowic i polska szkoła prawa międzynarodowego, Warszawa 2018, s. 59.

56 D. Girgensohn, Studenti, s. 165-167.

57 Szerzej o soborze w Konstancji jako rynku księgarskim zob. P. Lehmann, Konstanz und Basel als Büchermärkte während der grossen Kirchenversammlungen, w: tenże, Erforschung des Mittelalters. Ausgewählte Abhandlungen und Aufsätze, t. 2, Leipzig 1941, s. 253-279; J. Miethke, Die Konzilien als Forum der öffentlichen Meinung des 15. Jahrhunderts, „Deutsches Archiv für Erforschung des Mittelalters", 37, 1981, s. 757. O odkryciach kodeksów z tekstami antycznych autorów przez humanistów włoskich w czasie soboru w Konstancji zob. R. Sabbadini, Le scoperte dei codici latini e greci ne' secoli XIV e $X V$, t. 1, Firenze 1905, s. 75-82.

58 I. Malinowska-Kwiatkowska, I manoscritti giuridici, s. 161.

59 Zob. A. Sottili, I codici del Petrarca nella Germania occidentale, „Italia Medioevale e Umanistica”, 15, 1972, s. 361 n., 371 n., 385 n., 411.

${ }^{60}$ C. epist. XV, t. $2, \mathrm{nr} 82$.

${ }^{61}$ Mk 6,4; Łk 4,24; J 4,44; popularne jako przysłowie w różnych wersjach, m.in. „Nemo propheta sua splendidus in patria”; Walther, t. 3, Göttingen 1965, s. 93, nr 16422.

${ }^{62} \mathrm{Mk} 2,1-12$.

${ }^{63}$ Parafraza lub aluzja do $\mathrm{J} 4,38$.

${ }^{64} \mathrm{Wj}$ 16,3. 
serviens laboro in luto et latere ${ }^{65}$, minui hocmodo conveniat, vos videritis. Crescite igitur et multiplicamini, sed non more prothoplasti, terramque replete, sed non fructibus gradientibus super terram replete ${ }^{66}$. Suspicor tamen, ne vos, circa tantas rerum divicias lautisantes, fortune dulcis sapor ad sompnolenciam animi et mentis torpidi [sic! - wyd.] ocium provocet et statuat. Cavete igitur, frater care, ne occiositas, que mentis dicitur ignavia, vos a necessariis laudandisque labiorum studiis ad vana ac minus utilia resolvat negocia; nam iuxta Tulii in Tusculanis quescionibus sentenciam, quod: nil dulcius est ocio litterato ${ }^{67}$, scitis denique secundum Quintillianum, quod: ad omne votum fluente fortuna lascivit ocium ${ }^{68}$, propter quod dicebat Ovidius de Ponto: cernis, quod ignavum consummit inercia corpus ${ }^{69}$ et illud eiusdem in De Remediis: ocia si tollas periere Cupidinis arcus ${ }^{70}$ etc. Verumtamen, ut autummo, vos sicut et patres vestros vetus querela a labiorum insistencia nonnunquam abducit, iam amicorum eciam fictorum plerumque turba, quam nemo dinumerare poterit, non vocata ad mensam, semet ipsam convocat, que nedum bestiarum verum eciam hominum carnes vigente ventris ingluvie devorat, qui, si non fuerit saturitati, esurient, sicut canes murmurantes civitatem circuibunt $^{71}$. Contigitque experiencia docente inter insperatos comensales, ut alius esuriat alius ebrius sit ${ }^{72}$, nec minus quispiam talium de cacabo ligneo cernosam horridam visu gustuique terribilem cum hausorio in se fundens, quam qui vinum, quod cor hominis letificat ${ }^{73}$, bibens fundit refundit et in fundendo confundit amicos. Unde si circa huiusmodi leticiam animum delectari disponitis, poteritis dicere cum nostro Epicurio: gaudia sunt stomachi super omnia gaudia mundi ${ }^{74}$. Plura cito scribam per alium occurrentem etc. Datum Constancie anno $\mathrm{M}^{\circ} \mathrm{CCCCXVIII} \mathrm{[podkr.} \mathrm{A.H.]}{ }^{75}$.

${ }^{65}$ Jdt 5,10 .

${ }_{66}$ Parafraza Rdz 1,28.

${ }^{67}$ "Quid est enim dulcius otio litterato"; Cyceron, Tusculanae disputationes, V, XXXVII, 29-30 (M. Tulli Ciceronis Tusculanarum disputationum libri quinque, t. 2: Books III-V, wyd. T.W. Dougan, R.M. Henry, Cambridge 1934, s. 291).

$68,[\ldots]$ ad omne votum fluente fortuna lascivit otium”, Pseudo-Kwintylian, Declamationes, Declamatio III: Miles Marianus, XII, 16-17 (Declamationes XIX maiores Quintiliano falso ascriptae, wyd. L. Håkanson, Stuttgart 1982, s. 53).

${ }^{69}$ Parafraza z: „,ernis ut ignauum corrumpant otia corpus”; Owidiusz, Epistulae ex Ponto, I, V, 5 (Ovid, Epistulae ex Ponto. Book I, wyd. G. Tissol, Cambridge 2014, s. 41).

${ }^{70}$ Owidiusz, Remedia amoris, 139. N. Contieri błędnie zidentyfikowała ten cytat jako pochodzący z De remediis utriusque fortunae Petrarki ze względu na przywołanie tytułu jako „de remediis”; zob. taż, La fortuna del Petrarca in Polonia, s. 150.

71 Por. Ps 58,15-16.

721 Kor $11,21$.

73 Parafraza Syr 40,20.

${ }^{74}$ Popularny i często wykorzystywany w średniowieczu cytat, np. w traktacie dominikanina Henryka Suzona (zm. 1366), zob. Heinrich Seuses Horologium sapientiae, wyd. P. Künzle OP na podst. oprac. wstępnego D. Planzera OP, Freiburg 1977, s. 377; Walther, t. 2, Göttingen 1963, s. 227, nr 10246.

${ }^{75}$ C. epist. XV, t. 2, nr 82, s. 100 n.: „Sądziłem, że, zgodnie ze słowami Zbawiciela, prorok jest mało poważany w ojczyźnie, wy zaś, nie tylko w Kafarnaum, ale i we własnej ojczyźnie dzięki cudom oraz znakom jasno i cudownie błyszczycie, zbierając to, czego nie położyliście, itd. [...]. Dlatego zobaczcie, jeśli wam, którzy zasiadacie przed garnkami z mięsem itd., wzrastać przystoi, mnie zaś, który na obczyźnie służąc, podejmuję najcięższe trudy, umniejszyć się przystoi. Wzrastajcie więc, mnóżcie się i zapełniajcie ziemię, lecz nie na sposób pierwszego człowieka, lecz nie zapełniajcie ziemi przyjemnymi owocami. Obawiam się jednak, aby w was, żyjących w tak wielkich bogactwach, słodki smak fortuny nie spowodował i nie utrwalił ospałości ducha i bezczynności otępiałego umysłu. Strzeżcie się zatem, drogi bracie, aby bezczynność, która zwana jest gnuśnością umysłu, nie odciągnęła was od niezbędnych i godnych pochwały starań, skłaniając do próżnych i mniej pożytecznych zajęć; zgodnie z opinią Tulliusza w Rozmowach tuskulańskich, że nie ma nic słodszego niż czas poświęcony na rozrywkę intelektualną. Wiecie wreszcie, że według Kwintyliana: w pomyślnym czasie z każdym pragnieniem igra bezczynność, dlatego to mawiał Owidiusz z Pontu: zauważ, że bezczynność trawi ciało gnuśnego, i tenże w O lekarstwach: jeśli porzucisz wypoczynek, zniszczony zostanie łuk Kupidyna, itd. Niemniej jednak, podobnie jak jesienią, dawny żałosny głos niejednokrotnie odwodził was, jak i waszych ojców od wytrwałości warg, otóż liczny tłum fałszywych przyjaciół, którego nikt nie potrafi zliczyć, niewezwany na ucztę, sam się zwołuje i pożera nie tylko ciała zwierząt, ale i ludzi przez wielką żarłoczność brzucha. Ci, jeśli nie zostaną nasyceni, będą głodni i niczym psy warczące otoczą miasto. Zdarza się, jak uczy doświadczenie, że między przygodnymi biesiadnikami jeden łaknie, a drugi jest nasycony. Niekiedy też ktoś spośród nich nalewa sobie czerpakiem $z$ drewnianego garnca trunek o szpetnym wyglądzie i okropnym smaku, który rozwesela ludzkie serce podobnie jak wino, a pijąc, nalewa, dolewa i nalewając, myli przyjaciół. Zatem jeśli chcecie, aby wasz duch rozkoszował się tego rodzaju przyjemnościami, będziecie mogli powiedzieć za naszym Epikurem: uciechy brzucha są ponad wszelkie uciechy świata. Więcej napiszę wkrótce przez innego posłańca, gdy takowy się trafi itd. Dano w Konstancji, roku 1418" - tłum. A.H. Chciałabym wyrazić wdzięczność mgr Urszuli Zacharze-Związek (IH PAN) za konsultację fragmentów tłumaczenia. 
W pierwszej części Wolfram zamieścił cytaty biblijne, przy czym tylko pierwszy z nich wprowadził w sposób wyraźny poprzez wyrażenie ,iuxta sentenciam salvatoris”, pozostałe są cytatami niejawnymi lub aluzjami - jak wzmianka o Kafarnaum, stanowiąca w tym kontekście aluzję do uzdrowienia paralityka - ale należy sądzić, że były one czytelne dla adresata jako osoby duchownej ${ }^{76}$. To, że niektóre $\mathrm{z}$ nich są sparafrazowane, wiązać można $\mathrm{z}$ faktem, że najprawdopodobniej przytaczał je z pamięci. Tego rodzaju biblijne cytaty występowały również w innych znanych nam listach Piotra Wolframa ${ }^{77}$.

Wolfram, posługując się serią cytatów z autorów klasycznych, przestrzegał swojego konkurenta przed gnuśnością, w jaką można popaść, korzystając z dóbr doczesnych związanych z otrzymanym beneficjum, a także przed bezczynnością. Połączenie powiązanych tematycznie cytatów z autorów klasycznych nasuwa przypuszczenie, że zostały one zaczerpnięte $\mathrm{z}$ jakiegoś florilegium ${ }^{78}$. Część $\mathrm{z}$ nich funkcjonowała jako cytaty o tej samej długości, jak w liście Wolframa, a to może wskazywać, że Polak nie zaczerpnął ich z pierwotnego źródła, jakim był tekst autora starożytnego. Dodatkowo przywoływany przez Wolframa cytat przypisany Kwintylianowi w rzeczywistości jest cytatem z Pseudo-Kwintyliana, co raczej wskazuje na zaczerpnięcie go z florilegium, w którym przypisywany był Kwintylianowi.

Najbardziej prawdopodobne wydaje się, że Wolfram wykorzystał florilegium, które miał ze sobą w Konstancji - Compendium moralium notabilium Jeremiasza z Montagnone (BJ 1596, k. 10r-178v). W dziele tym udało się znaleźć trzy cytaty przywołane przez Wolframa: z Tusculanae disputationes Cycerona (dzieło to u Wolframa i u Jeremiasza z Montagnone zostało określone jako Tusculanarum

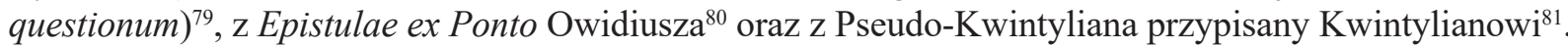
Również praktyka pisarska Wolframa widoczna w jego twórczości kaznodziejskiej przemawiałaby za tym,

76 O cytatach niemianowanych i kryptocytatach zob. H. Markiewicz, O cytatach i przypisach, Kraków 2004, s. 14 n.

77 Podobną aluzję biblijną znajdujemy w innym liście Wolframa skierowanym do wysokiego rangą dostojnika kościelnego (zapewne biskupa krakowskiego Wojciecha Jastrzębca), napisanym w Konstancji w 1418 r. Wolfram, w odpowiedzi na gratulacje z powodu mianowania referendarzem papieskim, odpowiadał, że nie jest godny rozwiązać rzemyka: „Scribitis michi, pater mi et domine, putastisque, quod sim domini nostri pape referandarius, qui non sum dignus solvere congiam eam [sic! - wyd.] insignis officii”. Prawdopodobnie congiam to błąd odczytu wydawcy albo kopisty, powinno być corigiam. W dalszej części tego zdania, pisząc o nadmiernym zwiększeniu liczby urzędników kurialnych, użył cytatu „multiplicati sunt super numerum” (Ps 39,6): „referandarii, sicuti et alii, pallatini, officiarii, maxime cubicularii, propter infestam nacionum regum et principum instanciam multiplicati sunt super numerum”. Poniżej w tymże liście też posługiwał się cytatami biblijnymi, np. pisząc o próbach uporządkowania na soborze kwestii prowizji na beneficja i trudnościach związanych z godzeniem sprzecznych stanowisk różnych nacji, użył zwrotu „turbati et moti sicut ebrius” (Ps 106,27): „que attenus [sic! - wyd.] quantum ad provisionem beneficiorum arestata est totaliter, propter nacionum diversitatem et adversitatem non modicam, volentibus quibusdam, ut papa se de nullo beneficiorum preter reservaciones in corpore iuris clausas impediat, aliis, quatenus medietas, nonnullis, ut tercia pars locorum ordinariis debeatur; sicque in isto rerum turbine turbati et moti sicut ebrius incedimus"; C. epist. XV, t. 2, nr 80, s. 97 n. W liście do papieża Marcina V z 13 XI 1418, wspominając o planach przeniesienia arcybiskupa gnieźnieńskiego Mikołaja Trąby na biskupstwo krakowskie, a biskupa krakowskiego Wojciecha Jastrzębca do Gniezna, Wolfram użył zwrotu, który można również uznać za sparafrazowany cytat biblijny (Łk 12,3): „quod pridem in aure dicebatur, nunc predicatur super tecta” („,o wcześniej było mówione na ucho, teraz rozgłaszane jest na dachach" - tłum. A.H.); C. epist. XV, t. 2, nr 91, s. 113; zob. też H. Likowski, Powstanie godności prymasowskiej arcybiskupów gnieźnieńskich. Ustęp z dziejów hierarchii kościoła polskiego, Przegl. Hist., 19, 1915, nr 2, s. 187-189.

78 Chciałabym wyrazić wdzięczność dr. Antoniemu Grabowskiemu (IH PAN) za wskazówkę dotyczącą florilegiów i antologii jako potencjalnego źródła cytatów dla Piotra Wolframa.

${ }^{79}$ Cytat ten w liście Piotra Wolframa brzmi: „nam iuxta Tulii in Tusculanis quescionibus sentenciam, quod: nil dulcius est ocio litterato"; C. epist. XV, t. 2, nr 82, s. 101. Cytat ten znajduje się u Jeremiasza z Montagnone w Compendium moralium notabilium, cz. 3, ks. 3, rubryka 1 (De philosophia et scientia litterarum): „Tullius in hortensio: Philosophia racionibus progredi debet [...]. Idem tusculanarum questionum [...]. Libro 5. Extra: Quid est dulcius ocio litterato”, BJ 1596, k. 93v; zob. [Hieremias de Montagnone], Epytoma sapientiae, Venetiis, wyd. Petrus Liechtenstein, 1505, 4 , k. 65r.

${ }^{80}$ W liście Piotra Wolframa: ,propter quod dicebat Ovidius de Ponto: cernis, quod ignavum consummit inercia corpus”; C. epist. XV, t. 2, nr 82, s. 101; zob. Jeremiasz z Montagnone, Compendium moralium notabilium, cz. 3, ks. 4, rubryka 8 (De labore oportuno et torpore seu mollicie): „Idem de Ponto lib. I C 5. Cernis quod ignavuum corrumpunt ocia corpus”, BJ 1596, k. 103v; zob. [Hieremias de Montagnone], Epytoma sapientiae, k. 73v.

${ }^{81}$ W liście Piotra Wolframa: „scitis denique secundum Quintillianum, quod: ad omne votum fluente fortuna lascivit ocium”; C. epist. XV, t. 2, nr 82, s. 101; zob. Jeremiasz z Montagnone, Compendium moralium notabilium, cz. 3, ks. 4, rubryka 8 (De labore oportuno et torpore seu mollicie): „Quintilianus declama 2 declama: Vacat viciis nostris et ad omne votum fluente fortuna lascivit ocium”, BJ 1596, k. 103v; zob. [Hieremias de Montagnone], Epytoma sapientiae, k. 73v. 
że część cytatów z autorów klasycznych zaczerpnął ze wspomnianej antologii Jeremiasza z Montagnone. W kazaniu z okazji elekcji Jana Pelli w 1421 r. na biskupstwo włocławskie, cytując Piotra z Blois, był świeżo po lekturze jego listów, które posiadał w rękopisie przepisanym w 1420 r. (BCzart. 2008) $)^{82}$

Rozumienie pojęcia otium w liście Wolframa, zilustrowane przytaczanymi cytatami, jest ambiwalentne. $\mathrm{Z}$ jednej strony, podając cytat z Remedia amoris Owidiusza, posługiwał się tym pojęciem zgodnie $\mathrm{z}$ negatywnym rozumieniem patrystycznym utrwalonym $\mathrm{w}$ średniowieczu ${ }^{83}$. Z drugiej strony, przywołując cycerońskie „nil est dulcius otio litterato”, Polak zbliżał się do klasycznego rozumienia tego pojęcia. J. Domański wskazywał, że takie niejednoznaczne traktowanie otium bliskie jest poglądom Petrarki (a być może nimi uwarunkowane). Petrarka rozróżniał bowiem dwa rodzaje otium - pierwszy, tożsamy z bezczynnością, i drugi, zgodny z rozumieniem klasycznym, stanowiący pracowity wypoczynek polegający na szlachetnych zajęciach, takich jak np. lektura książek ${ }^{84}$. Jednak również w Compendium moralium notabilium trzy cytaty dotyczące otium wykorzystane przez Wolframa zamieszczone są w różnym kontekście. Wspomniany cytat z Tusculanae disputationes Cycerona przedstawiający wypoczynek $\mathrm{w}$ pozytywnym znaczeniu występuje $\mathrm{w}$ tym florilegium $\mathrm{w}$ rozdziale poświęconym filozofii i literaturze ${ }^{85}$, za to cytaty z Epistulae ex Ponto Owidiusza oraz z Pseudo-Kwintyliana, odnoszące się do negatywnych aspektów bezczynności, znajdowały się w rozdziale na temat właściwej pracy oraz gnuśności ${ }^{86}$.

Oczywiście Compendium moralium notabilium nie jest jedynym źródłem, z którego mógł korzystać Wolfram. Wspomniane cytaty były wielokrotnie wykorzystywane w średniowieczu. Ten sam cytat z Epistulae ex Ponto Owidiusza został użyty m.in. przez Wincentego z Beauvais i Jana z Salisbury ${ }^{87}$, a cytaty z Remedia amoris Owidiusza i Pseudo-Kwintyliana można też znaleźć w popularnym w XIV i XV w. florilegium Summa de exemplis ac similitudinibus rerum Giovanniego da San Gimignano (zm. ok. 1333) w rozdziale De negligentia ${ }^{88}$. Wolfram mógł znać Policraticusa Jana z Salisbury, gdyż posiadał do niego alfabetyczną konkordancję (BJ 344, k. 141r-183v), nie ma natomiast dowodów na to, że znał dzieło Giovanniego da San Gimignano.

Trudno też przypuszczać, aby Piotr Wolfram - gdyby samodzielnie wybierał cytaty na temat odpoczynku z dzieł autorów starożytnych - zdecydował się akurat na te, które w bardzo podobnym brzmieniu (i o tej samej długości) można znaleźć w takim kontekście w antologiach średniowiecznych. Jeśliby zaś czytał przywoływane dzieła klasyków w całości, to taki wybór cytatów należałoby uznać za podyktowany wcześniejszą już erudycją zaczerpniętą z florilegiów.

Jeśli pominąc cytaty, to sam styl listów Wolframa nie daje podstaw, aby uznać go za prekursora humanizmu. Polak stosował w listach średniowieczną formę vos, podczas gdy Petrarka, a za nim humaniści włoscy, w swoich listach używali już klasycznej formy tu. Mowę zależną wprowadzał za pomocą quod, a nie przez wykorzystanie klasycznej konstrukcji z użyciem accusativus cum infinitivo, tak jak Petrarka i humaniści włoscy. Również pod względem formalnym listy Wolframa różnią się od listów Petrarki i humanistów włoskich, stosujących klasyczne formuły salutatio i datacji ${ }^{89}$. Styl Wolframa, dość

${ }^{82}$ Zob. wyżej, przyp. 34.

${ }^{83}$ B. Vickers, Leisure and Idleness in the Renaissance. The Ambivalence of Otium, „Renaissance Studies”, 4, 1990, nr 2, s. $107-154$.

${ }^{84}$ Petrarka, De remediis utriusque fortunae, I, 21; zob. A. Lee, Petrarch and St. Augustine. Classical Scholarship, Christian Theology and the Origins of the Renaissance in Italy, Leiden 2012, s. 117 n.

${ }^{85}$ Cz. 3, ks. 3, rubryka 1: De philosophia et scientia litterarum; zob. przyp. 79.

${ }^{86}$ Cz. 3, ks. 4, rubryka 8: De labore oportuno et torpore seu mollicie; zob. przyp. 80 i 81

87 Zob. Walther, t. 2, s. 30, nr 2639; s. 109; B. Vickers, Leisure and Idleness in the Renaissance, s. 109.

${ }^{88}$ „Ovid I de remediis, Ocia si tollas, perire cupidinis Arcus [...] Quintilianus causa I 3: Ad omne votum fluente fortuna lascivit ocium et causa quarta. Necesse est, ut in facinus ardor ociusus etumpat"; Joannes de Sancto Geminiano, Summa de exemplis et rerum similitudinibus, Lugduni, in officina Q. Philippi Tinghi, apud Simphoprianum Beraud et Stephanum Michaelem, $1585,4^{\circ}$, s. 305. Szerzej o Giovannim da San Gimignano zob. S. Vecchio, Giovanni da San Gimignano, w: Dizionario Biografico degli Italiani, t. 56, Roma 2001, s. 206-210; taż, „Exempla de legibus”. Le similitudini giuridiche di Giovanni da San Gimignano, w: , Verbum” e ,ius”. Predicazione e sistemi giuridici nell'Occidente medievale / Preaching and Legal Frameworks in the Middle Ages, red. L. Gaffuri, R.M. Parrinello, Firenze 2018, s. 335.

${ }^{89}$ Zwyczaj zwracania się do adresata w drugiej osobie liczby pojedynczej zaczął się upowszechniać w Polsce o wiele później niż we Włoszech; Mikołaj Lasocki w liście do Guarina z Werony (1437) stosował tę formę, ale jeszcze w 1467 r. nie była 
ozdobny i zawiły, pełen wyszukanych i nieraz nieznanych łacinie antycznej słów, obfitujący w aluzje, cytaty i długie wyliczenia, odpowiadał raczej regułom późnośredniowiecznej ars dictandi niż eleganckiej prostocie wprowadzonej przez Petrarkę, dbającego także, aby oczyszczać język ze średniowiecznych „barbaryzmów”90. Jeszcze większy dystans dzieli łacinę Wolframa od łaciny cycerońskiej, którą posługiwali się współcześni mu florenccy humaniści: Leonardo Bruni, Niccolò Niccoli i Poggio Bracciolini ${ }^{91}$.

\section{Wnioski}

Przykład listów Piotra Wolframa pokazuje, że cytaty same w sobie, bez uwzględnienia innych czynników, pogłębionej analizy kontekstu i źródła, z jakiego zostały zaczerpnięte, nie mogą być wyłącznym miernikiem określającym, czy dany tekst jest „,́́redniowieczny”, czy „humanistyczny”. Cytaty z Owidiusza, Cycerona i Pseudo-Kwintyliana, które znajdujemy w listach Wolframa, występowały też w średniowiecznych florilegiach w tej samej albo bardzo zbliżonej postaci (taka sama długość cytatu, określenie autora i dzieła, z którego zaczerpnięto cytat). Za tym, że Wolfram zaczerpnął swoje cytaty właśnie z tego rodzaju wtórnego źródła, przemawia jego biblioteka, w dużej mierze złożona z repertoriów, kompendiów, konkordancji alfabetycznych do znanych dzieł, dzięki którym łatwo można było odnaleźć szukaną kwestię. Najbardziej prawdopodobne wydaje się, że korzystał z tego, co posiadał, czyli m.in. Compendium moralium notabilium Jeremiasza z Montagnone, które miał ze sobą w Konstancji, skąd pisał wspomniane listy (trzy zidentyfikowane wspólne cytaty). Za tym, że Wolfram cytował dzieła autorów antycznych za pośrednictwem florilegium, przemawiać może fakt, że przywoływany przez niego cytat zaczerpnięty jakoby z Kwintyliana w antologiach średniowiecznych był przypisywany temuż autorowi, ale w rzeczywistości nie pochodził od niego.

Cytat z dzieła Petrarki u Wolframa odróżnia się od cytatów z Owidiusza, Cycerona i Kwintyliana, gdyż jest nieco sparafrazowany, co pozwala podejrzewać, że Wolfram mógł zaczerpnąć go z De remediis utriusque fortunae, zwłaszcza że kontekst też się zgadza. Nie można jednak stwierdzić, czy Wolfram miał to dzieło w swojej bibliotece, czy też, będąc w Konstancji, skorzystał z cudzego egzemplarza albo też przejął cytat w sposób pośredni (z innego tekstu). Nie można jednak mówić o głębszej recepcji dzieł Petrarki przez Wolframa, ponieważ nie naśladował jego stylu ani nie rozwijał szerzej podejmowanych przez niego rozważań. Należy sądzić, że jako osoba wykształcona na uniwersytetach włoskich i bywała w Kurii Rzymskiej, wiedział, jacy autorzy są „modni”, na kogo dobrze jest się powołać, by pochwalić się elokwencją i przyspieszyć swoją karierę, zwłaszcza że jako syn mieszczański musiał się o to szczególnie starać ${ }^{22}$. Rodzaj erudycji widoczny w jego listach wydaje się typowy raczej dla środowiska

ona w Polsce rozpowszechniona, gdyż Sędziwój z Czechla w liście do Jana Lutka z Brzezia domagał się, aby zwracać się w drugiej osobie liczby pojedynczej, a nie mnogiej; zob. R. Sabbadini, Epistolario di Guarino Veronese, t. 2, Venezia 1916, nr 716, s. 322 n.; J. Domański, Poczatki humanizmu, s. 116; R. Antognini, „Familiarium rerum liber”. Tradizione materiale e autobiografia, w: Petrarch and the Textual Origins of Interpretation, red. T. Barolini, H. Wayne Storey, Leiden-Boston 2007, s. 222; S. Rizzo, Il latino del Petrarca e il latino dell'umanesimo, w: Il Petrarca latino e le origini dell'umanesimo. Atti del Convegno internazionale, Firenze, 19-22 maggio 1991, „Quaderni petrarcheschi”, 9-10, 1992-1993 [wyd. 1997], s. 349-365; L. Winniczuk, Wstęp, w: Jan Ursyn z Krakowa, Modus epistolandi cum epistolis exemplaribus et orationibus annexis, tłum., wstęp i objaśn. L. Winniczuk, Wrocław 1957, s. VIII.

${ }^{90}$ Różnicę między kunsztownym stylem średniowiecznym a stylem humanistycznym w epistolografii pokazała S. Rizzo, zestawiając obok siebie list kanclerza cesarskiego Jana ze Środy do Petrarki z 1352 lub 1353 r., pełen wyszukanych zwrotów, metafor i aluzji utrudniających odnalezienie sensu, z odpowiedzią poety, napisaną w sposób bardzo precyzyjny i wyważony; taż, Il latino del Petrarca nelle „Familiari”, w: The Uses of Greek and Latin. Historical Essays, red. A.C. Dionisotti, A. Grafton, J. Kraye, London 1988, s. 41 n.

${ }^{91}$ Leonardo Bruni krytycznie oceniał łacinę Petrarki, dostrzegając jej niedoskonałości w stosunku do wzorcowej jego zdaniem prozy Cycerona; zob. S. Rizzo, Il latino del Petrarca e il latino dell'umanesimo, s. 360 n.; R. Fubini, All'uscita dalla Scolastica medievale: Salutati, Bruni, e i „Dialogi ad Petrum Histrum”, „Archivio Storico Italiano”, 150, 1992, s. 1069, 1071 n.

92 Bulla Jana XXIII z 1414 r. ograniczała osobom pochodzenia nieszlacheckiego możliwość ubiegania się o beneficja w kapitułach gnieźnieńskiej i krakowskiej; A. Radzimiński, Duchowieństwo kapitut katedralnych w Polsce XIV i XV wa tle porównawczym. Studium nad rekrutacją i drogami awansu, Torun 1995, s. 92. 
prawników związanych z Uniwersytetem Padewskim jak Franciszek Zabarella niż dla humanistów florenckich takich jak Leonardo Bruni czy Poggio Bracciolini. Listy Wolframa, zawierające odwołania, które musiały być przynajmniej ogólnie rozpoznawalne dla ich odbiorcy, pokazują, że w późnym średniowieczu do kanonu auctoritates wykorzystywanych przez polskich autorów, takich jak Seneka i Cyceron, dołączył też Petrarka ${ }^{93}$.

\section{Quotations in Piotr Wolfram's letters - between the Middle Ages and Renaissance humanism}

Summary: The article is devoted to the role of quotations as a tool to measure the impact of Renaissance humanism on the example of letters of Piotr Wolfram (d. 1428), a lawyer educated in Padua and Bologna, and a participant of the Council of Constance. He was regarded as one of the precursors of humanism in Poland for he was the first Polish author to quote Petrarch. Many scholars treated numerous quotations in his letters taken from Quintilian, Ovid, and Cicero as the evidence for his humanistic formation. The present article, however, pays attention to other sources of quotations, very popular in the Middle Ages, i.e. florilegia, collections of exempla, encyclopaedias and other works of this type. An argument in favour of such indirect sources is the content of Wolfram's library with various kinds of repertories, concordances, and anthologies, as well as his writing practice evident in his sermons. Quotes from ancient authors used by Wolfram were quite popular in the Middle Ages, three of them were found in his exemplar of Compendium moralium notabilium by Jeremiah de Montagnone. The quotation from Petrarch's De remediis utriusque fortunae given by Wolfram in the form of paraphrase could indicate that he knew the text, but does not prove his humanistic interests. At the same time, the very style of Wolfram's letters remained medieval, quite ornate and sophisticated, far both from elegant simplicity and precision introduced by Petrarch, and Ciceronian Latin of Leonardo Bruni.

Nota o autorze: Anna Horeczy, adiunkt w Zakładzie Studiów Nowożytnych Instytutu Historii im. Tadeusza Manteuffla Polskiej Akademii Nauk. Zainteresowania badawcze: recepcja włoskiej kultury intelektualnej w Polsce w XV i XVI w.

Author: Anna Horeczy, assistant professor at the Department of Early Modern History of the Tadeusz Manteuffel Institute of History, Polish Academy of Sciences. Her research interests include reception of Italian intellectual culture in Poland in the $15^{\text {th }}$ and $16^{\text {th }}$ centuries.

Instytut Historii im. Tadeusza Manteuffla Polskiej Akademii Nauk

ul. Rynek Starego Miasta 29/31

00-272 Warszawa

e-mail: ahoreczy@ihpan.edu.pl

\section{Bibliografia}

\section{Źródła drukowane}

Codex epistolaris saeculi decimi quinti, t. 2: 1382-1442, oprac. A. Lewicki, Kraków 1891

[Hieremias de Montagnone], Epytoma sapientiae, Venetiis, wyd. Petrus Liechtenstein, 1505, $4^{\circ}$

Joannes de Sancto Geminiano, Summa de exemplis et rerum similitudinibus, Lugduni, in officina Q. Philippi Tinghi, apud Simphoprianum Beraud et Stephanum Michaelem, 1585

M. Tulli Ciceronis Tusculanarum disputationum libri quinque, t. 2: Books III-V, wyd. T.W. Dougan, R.M. Henry, Cambridge 1934

Ovid, Epistulae ex Ponto. Book I, wyd. G. Tissol, Cambridge 2014

Petrarca F., Liber sine nomine, wyd. G. Cascio, Firenze 2015

${ }^{93}$ K. Bracha, Nauczanie kaznodziejskie, s. 96. Kolejne przypadki cytowania Petrarki przez Polaków przypadają dopiero na okres soboru w Bazylei - kazania Mikołaja Kozłowskiego czy Jana Elgota; zob. N. Contieri, La fortuna del Petrarca in Polonia, s. 152-155; M. Kowalczyk, Krakowskie mowy, s. 38, 138. 
Pétrarque, Les remèdes aux deux fortunes, t. 1: Texte et traduction, wyd. Ch. Carraud, Grenoble 2002 Sabbadini R., Epistolario di Guarino Veronese, t. 2, Venezia 1916

\section{Opracowania}

Antognini R., ,Familiarium rerum liber”. Tradizione materiale e autobiografia, w: Petrarch and the Textual Origins of Interpretation, red. T. Barolini, H. Wayne Storey, Leiden-Boston 2007, s. 205-229

Bracha K., Nauczanie kaznodziejskie w Polsce późnego średniowiecza. „Sermones dominicales et festivales” z tzw. kolekcji Piotra z Miłosławia, Kielce 2007

Domański J., Scholastyka i początki humanizmu w myśli polskiej XV wieku, Warszawa 2011

Drabina J., Papiestwo a Polska w latach 1384-1434, Kraków 2003

Hooper L.E., Exile and Petrarch's Reinvention of Authorship, „Renaissance Quarterly”, 69, 2016, nr 4, s. 1217-1256

Knapek E., Rękopisy średniowieczne w zbiorach Biblioteki Naukowej PAU i PAN w Krakowie, „Rocznik Biblioteki Naukowej PAU i PAN w Krakowie", 57, 2012, s. 9-47

Kowalska-Pietrzak A., Prałaci i kanonicy kapituły łęczyckiej do schyłku XV wieku, Łódź 2004

Kowalski M.D., Dlaczego warto było zostać kolektorem? Kariery papieskich kolektorów generalnych w Polsce w XV wieku, Rocz. Hist., 80, 2014, s. 133-154

Lee A., Petrarch and St. Augustine. Classical Scholarship, Christian Theology and the Origins of the Renaissance in Italy, Leiden 2012

Lichończak-Nurek G., Wojciech herbu Jastrzębiec, arcybiskup i mą̇ stanu (ok. 1362-1436), Kraków 1996

Malinowska-Kwiatkowska I., I manoscritti giuridici bolognesi al collegium iuridicum dell'Università Jagellonica (il lascito di Piotr Wolfram), w: Laudatio Bononiae. Atti del Convegno storico italo-polacco svoltosi a Bologna dal 26 al 31 maggio 1988 in occasione del Nono Centenario dell'Alma Mater Studiorum, red. R.K. Lewański, Bologna-Varsavia 1990, s. 161-166

Ożóg K., Intelektualiści w stużbie Królestwa Polskiego 1306-1382, Kraków 1995

Ożóg K., Kultura umysłowa w Krakowie w XIV wieku. Środowisko duchowieństwa świeckiego, Wrocław 1987

Pelán J., Il „De remediis” di Francesco Petrarca e la sua fortuna in Boemia, w: Petrarka a jedność kultury europejskiej. Materiaty międzynarodowego zjazdu, Warszawa, 27-29 V 2004 / Petrarca e l'unità della cultura europea. Atti del convegno internazionale, red. M. Febbo, P. Salwa, Warszawa 2005, s. 339-352

Petryszak B., Кар’єри публічних нотаріїв у Львові XV-XVI cm, „Średniowiecze Polskie i Powszechne”, 3 (7), 2011, s. 171-185

Petryszak В., Львівський період діяльності Петра Вольфрама (1402-1407 рр.), w: Lwów: miasto - społeczeństwo - kultura. Studia z dziejów Lwowa, t. 7, red. K. Karolczak, Ł.T. Sroka, Kraków 2010, s. 179-194

Secchi Tarugi L., La dimensione europea della cultura di Francesco Petrarca, w: Petrarka a jedność kultury europejskiej. Materiały międzynarodowego zjazdu, Warszawa, 27-29 V 2004 / Petrarca e l'unità della cultura europea. Atti del convegno internazionale, red. M. Febbo, P. Salwa, Warszawa 2005, s. 13-19

Starzyński M., Archiwa miejskie w średniowiecznych strategiach pamięci, w: Przeszłość w kulturze średniowiecznej Polski, t. 1, red. J. Banaszkiewicz, A. Dąbrówka, P. Węcowski, Warszawa 2018, s. 447-475

Vecchio S., „Exempla de legibus”. Le similitudini giuridiche di Giovanni da San Gimignano, w: „,Verbum” $e$, ,ius”. Predicazione e sistemi giuridici nell'Occidente medievale / Preaching and Legal Frameworks in the Middle Ages, red. L. Gaffuri, R.M. Parrinello, Firenze 2018, s. 325-345 